\title{
Glacial landform-sediment assemblages in the Canadian High Arctic and their implications for late Quaternary glaciation
}

\author{
C. Ó Cofaigh, ${ }^{1 *}$ D.S. Lemmen, ${ }^{2}$ D.J.A. Evans, ${ }^{3}$ J. Bednarski ${ }^{2}$ \\ ${ }^{1}$ Department of Earth and Atmospheric Sciences, University of Alberta, Edmonton, Alberta T6G 2E3, Canada \\ ${ }^{2}$ Terrain Sciences Division, Geological Survey of Canada, Calgary, Alberta T2L 2A7, Canada \\ ${ }^{3}$ Department of Geography and Topographic Science, University of Glasgow, Glasgow G12 8QQ, Scotland
}

\begin{abstract}
Modern terrestrial glaciers in the Canadian High Arctic range from polythermal to cold-based. Where polythermal glaciers override thick unconsolidated sediment, longitudinal compression and glaciotectonic thrusting produce thrust-block moraines. In contrast, the dominant geomorphic record of cold-based glaciers consists of lateral and proglacial meltwater channels. Geomorphic and sedimentary evidence indicates that late Quaternary fiord glaciers were also characterized by variations in basal thermal regime. Erratic dispersal trains and striated bedrock record the flow of warmbased ice during the Last Glacial Maximum. Emergent grounding-line fans and morainal banks, deposited during deglaciation, consist of heterogeneous glaciomarine deposits that record well-developed subglacial drainage and high sedimentation rates. However, in other fiords, subaqueous outwash and fine-grained glaciomarine deposits are absent and deglaciation is recorded by lateral meltwater channels graded to raised glaciomarine deltas, suggesting these glaciers were predominantly cold-based during retreat. Regionally, deglacial depocentres are located at pinning points within fiords and a prominent belt of glaciogenic landforms at fiord heads records stabilization of ice margins during early Holocene retreat, rather than the limit of late Quaternary glaciation. Collectively, these observations refute previous reconstructions which inferred a climatically controlled switch from cold- to warm-based thermal conditions in fiord glaciers during early Holocene deglaciation, and indicate that the dominant controls on thermal regime were glaciological.
\end{abstract}

\section{INTRODUGTION}

In modern glacioterrestrial and glaciomarine settings, characteristic glacial landform-sediment assemblages are indicative of particular basal thermal regimes. Landformsediment assemblages, produced by terrestrial and marine warm-based glaciers, typically reflect the dominant influences of extensive basal sliding, subglacial sediment deformation and well-developed subglacial drainage systems (e.g. Boulton, 1972; Powell and Molnia, 1989). Although these processes have been observed beneath some contemporary cold-based glaciers (Echelmeyer and Wang, 1987), their magnitude is limited compared to warm-based glaciers. In general, the sedimentary and geomorphic products of coldbased ice masses reflect an absence of subglacial meltwater, basal sliding and subglacial deformation (e.g. Rains and Shaw, 1981; Powell and others, 1996). Such information has been utilized in studies of ancient glaciogenic landforms and sediments to make inferences about past basal thermal regime (e.g. Clayton and Moran, 1974).

The objective of this paper is to describe glacial landform-sediment assemblages produced by late Quaternary

\footnotetext{
* Present address: Bristol Glaciology Centre, School of Geographical Sciences, University of Bristol, Bristol BS8 1SS, England
}

fiord glaciers on Ellesmere and Axel Heiberg Islands in the Canadian High Arctic (Fig. 1) and to discuss the implications of these data for late Quaternary glaciation in the region, focusing on basal thermal regime and controls thereon, with reference to appropriate modern analogues. We first highlight elements of the modern glacioterrestrial and glaciomarine environments.

Previous work on this topic from Ellesmere Island argued that well-developed late Quaternary deglacial landformsediment assemblages at many fiord heads in the region mark both the limit of the last glaciation and record a transient, climatically controlled switch in basal thermal regime from cold- to warm-based, which contrasts with inferred coldbased conditions during the Last Glacial Maximum (LGM) and the present (e.g. England, 1987; Lemmen, 1990; Stewart, 1991; Evans and England, 1992). In this paper, we present evidence for spatial variation in the basal thermal regime of both past and present glaciers in the region. We argue that, during the late Quaternary, this variation was controlled by glaciological factors rather than by climate, and that the location of glacial landform-sediment assemblages reflects the control of fiord bathymetry on glacier dynamics during deglaciation and not a restricted LGM.

\section{MODERN GLAGIAL ENVIRONMENTS}

Modern ice cover on Ellesmere and Axel Heiberg Islands 


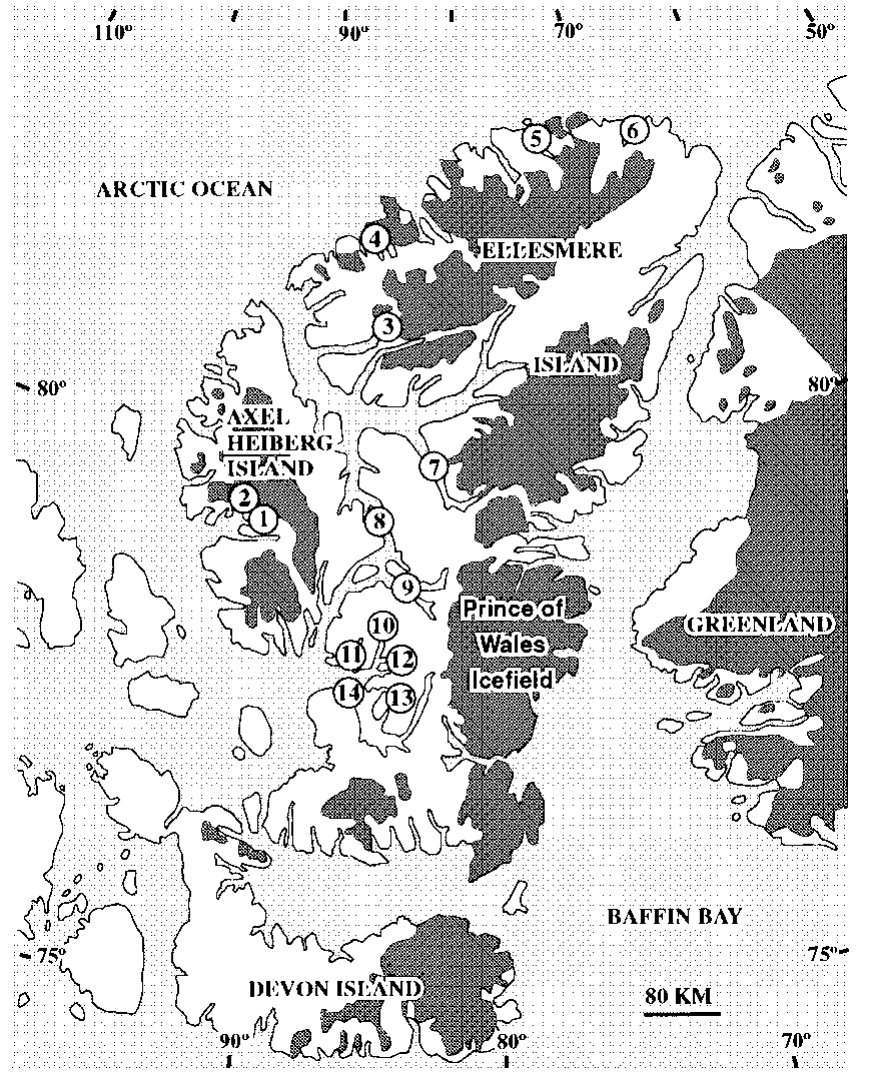

Fig. 1. Numbered sites on Ellesmere and Axel Heiberg Islands referenced in text. (1) Expedition Fiord; (2) Iceberg Glacier; (3) Otto Glacier; (4) Phillips Inlet; (5) Disraeli Fiord; (6) Clements Markham Inlet; (7) Cañon Fiord; (8) Eureka Sound; (9) Bay Fiord; (10) Trold Fiord; (11) Blind Fiord; (12) Starfish Bay; (13) Svendsen Peninsula; (14) Baumann Fiord. Contemporary ice cover is shaded dark.

(between $76^{\circ}$ and $83^{\circ} \mathrm{N}$; Fig. 1) predominantly consists of ice caps feeding valley and piedmont outlet glaciers that frequently extend to the sea. Ice thickness ranges from 300-800 $\mathrm{m}$ for ice caps, and 200-500 $\mathrm{m}$ for outlet glaciers (Koerner, 1989). Although there have been some detailed studies of terrestrial glaciology and glacial geomorphology (e.g. Kälin, 1971; Müller, 1976; Blatter, 1987; Evans, 1989a), systematic investigations of glacial geomorphic processes, sediment transport and deposition are very limited. Studies of the glaciomarine environment have focused on contemporary fiord sedimentation (e.g. Gilbert and others, 1993; Expedition Fiord; site 1, Fig. 1), however, the basal thermal regime of marine-terminating glaciers remains largely unknown. We highlight below salient aspects of modern glacial environments in the region that we feel are most relevant to the interpretation of past glacial landform--sediment assemblages.

Plateau icefields, cirque glaciers and thin, low-activity terrestrial outlet glaciers are characterized by a predominantly cold-based thermal regime (Koerner, 1989). Associated geomorphic processes are largely confined to glaciofluvial erosion of meltwater channels. Because drainage on these glaciers occurs in supraglacial or ice-marginal positions, sequential retreat is typically recorded by nested lateral meltwater channels where suitable topography exists (Fig. 2a). On eastern Ellesmere Island, intact, dead plant communities which were overrun by ice at least 400 years ago, are currently being exposed at the margin of a retreating outlet glacier (Bergsma and others, 1984) and testify to the lack of active basal erosion.

On northern Ellesmere Island, some outlet glaciers form floating ice tongues where they enter fiords and this likely reflects a cold-based thermal regime (cf. Powell, 1984). The only study of contemporary sedimentation in such an environment is from Disraeli Fiord (site 5, Fig. 1; Lemmen, 1990), where sedimentation rates of $0.1 \mathrm{~mm} \mathrm{a}^{-1}$, are among the lowest reported for any fiord environment and imply that the nearby glaciers are cold-based. Uppermost sediments from the inner fiord to within $<1 \mathrm{~km}$ of the floating ice tongue consist of massive to faintly laminated silty clay, devoid of coarser sediment except for rare sandy bands interpreted as sediment gravity-flow deposits.

Terrestrial polythermal outlet glaciers have been documented at several localities on Ellesmere and Axel Heiberg Islands and they commonly contain both subglacial and englacial drainage systems (Iken, 1972; Müller, 1976; Blatter, 1987; Skidmore and Sharp, in press). In many valley bottoms and fiord heads, Quaternary sediments are prone to excavation by these glaciers, particularly where permafrost thickness is variable. The primary landform resulting from this excavation is nested, thrust-block moraines composed of alluvial, glaciolacustrine and glaciomarine sediments (Kälin, 1971; Evans, 1989b; Fig. 2b). Thrust blocks provide a sediment source for entrainment if subsequently overridden, and this
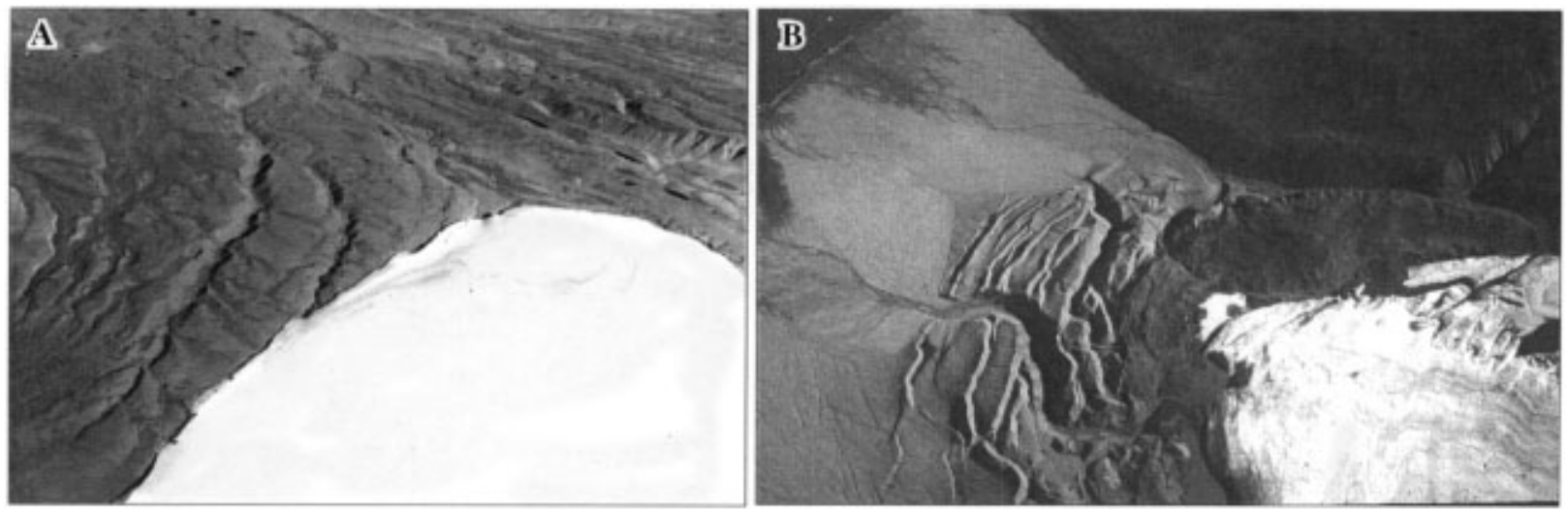

Fig. 2. Contemporary terrestrial ice-marginal environments: (a) lateral meltwater channels along margin of outlet glacier, Axel Heiberg Island; (b) thrust-block moraine, Axel Heiberg Island, incised by proglacial meltwater channels. The prominent arcuate end moraine records the terminus position contemporaneous with thrusting. 

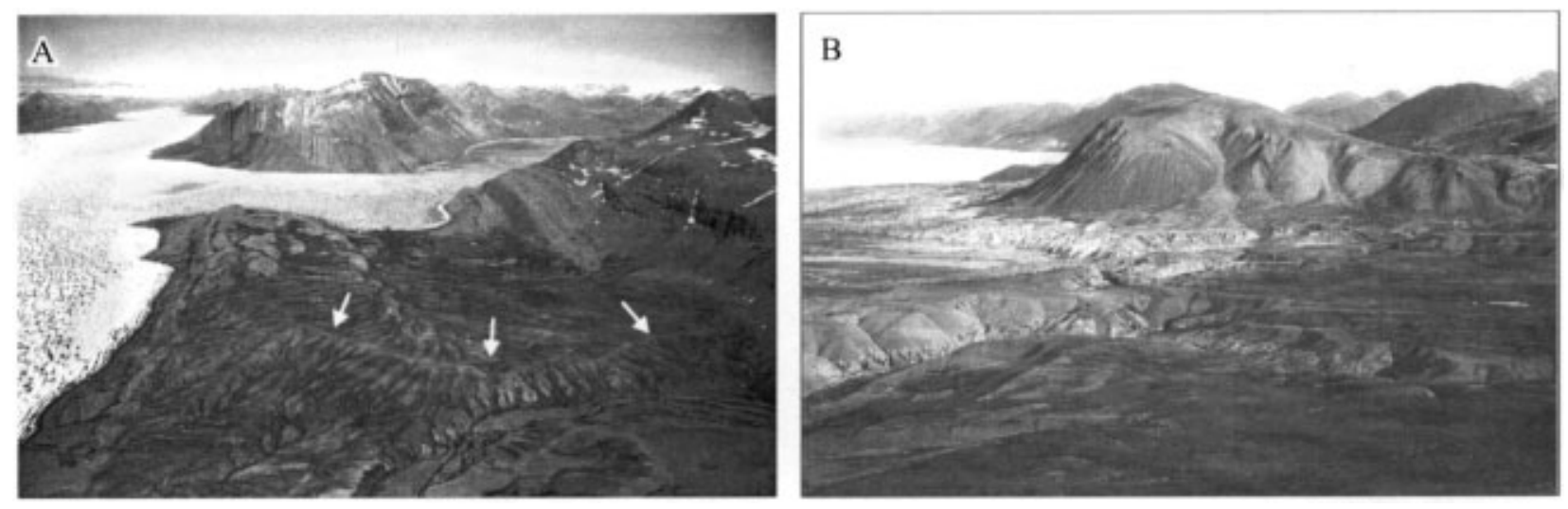

Fig. 3. Late Quaternary deglacial landform-sediment assemblages: (a) arcuate morainal bank (arrowed) inset between fiord side and ice-moulded bedrock highs, Trold Fiord, Ellesmere Island ( site 10, Fig. 1); (b) emergent glaciomarine sediments at fiord head, Clements Markham Inlet, Ellesmere Island ( site 6, Fig. 1), including grounding-line fan deposits overlain by flat-topped, ice-contact deltas.

augments other entrainment processes in polythermal outlet glaciers, such as overriding of frontal aprons (Evans, 1989a) and refreezing at snouts (Boulton, 1972). Supraglacial debris is delivered to glacier surfaces from valley sides (where suitable topography exists), as well as by aeolian processes, although heavily debris-covered glaciers are rare.

Marine-terminating, polythermal glaciers have not been documented to date in the Canadian High Arctic. Cañon Fiord on Ellesmere Island (site 7, Fig. 1) is an ice-contact environment with estimated sedimentation rates of $1-2 \mathrm{~mm} \mathrm{a}^{-1}$, six kilometers from the ice margin (Gilbert and Aitken, in press). The order of magnitude difference in sedimentation rates between Cañon and Disraeli Fiords (Lemmen, 1990) raises the possibility that the former is fed by a polythermal glacier. A warm-based or polythermal basal regime for some marine-terminating glaciers on Ellesmere and Axel Heiberg Islands is also implied by the documented surging of Otto Glacier (site 3, Fig. 1) on northwestern Ellesmere Island (Hattersley-Smith, 1969) and morphologic evidence for past surging at other sites (e.g. Iceberg Glacier, Axel Heiberg Island; site 2, Fig. 1; Ommanney, 1969).

\section{LATE QUATERNARY GLACIAL ENVIRONMENTS}

\section{Evidence of warm-based ice during the LGM}

Dispersal trains and ice-moulded bedrock

Dispersal trains of granitic till extend westwards from the

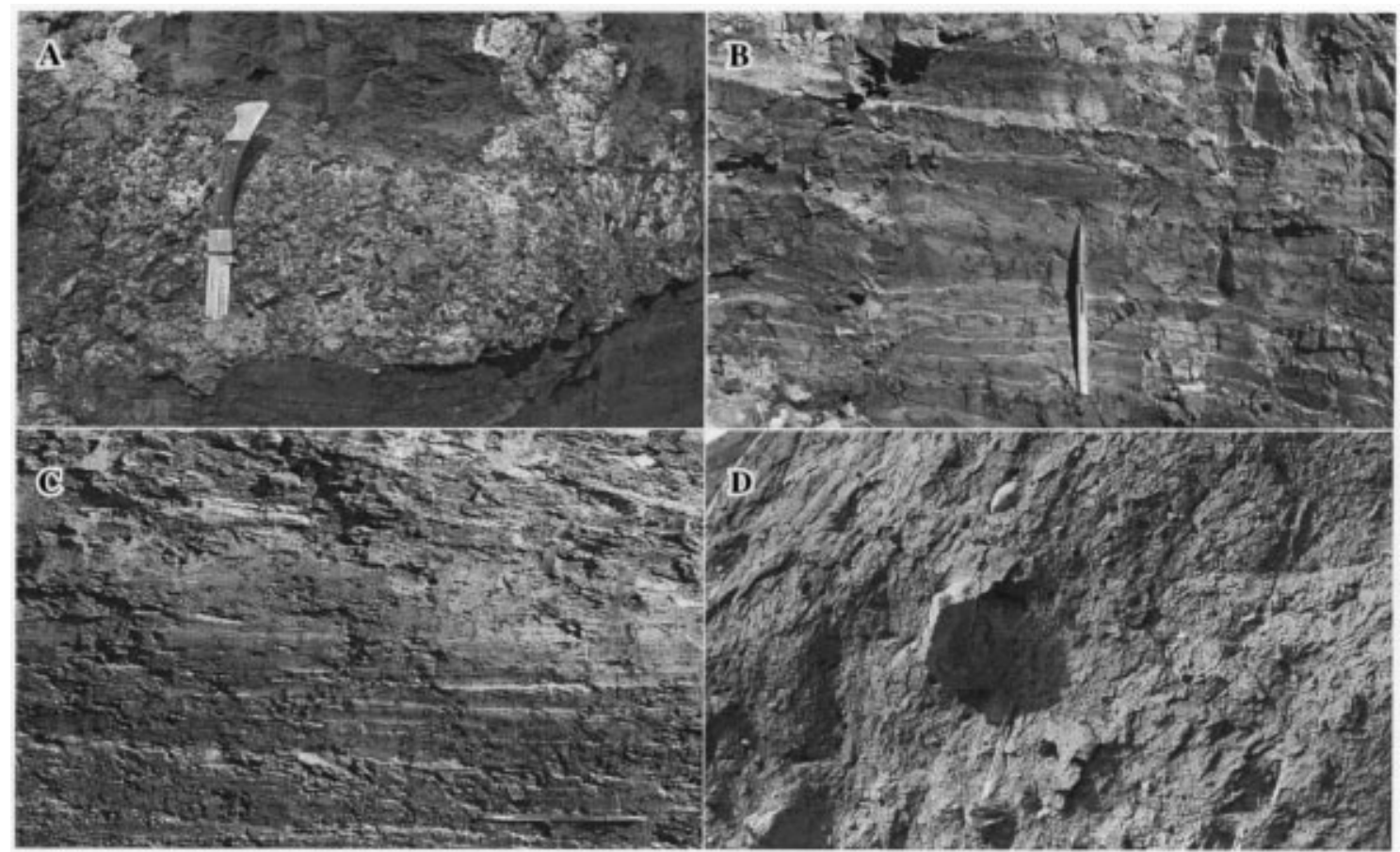

Fig. 4. Early Holocene glaciomarine sediments in grounding-line fans and morainal banks: (a) channelized, normally graded gravel with sharp erosional contacts, interpreted as high-density turbidity-current deposit; ( $b$ ) horizontally laminated sand-silt couplets with occasional small dropstones, interpreted as suspension deposits from turbid plume with limited iceberg-rafted debris; (c) horizontally laminated sand-silt couplets grading upwards to massive, matrix-supported diamict, interpreted as suspension deposits overlain by iceberg-rafted diamict; (d) stacked beds of massive diamict, separated by sharp contacts or thinly bedded horizontally laminated sand with outsized clasts at bed tops, interpreted as subaqueous cohesive debris-flow deposits. 


$\begin{array}{lll}\text { Landform-sediment } & \text { Lithofacies } & \text { Interpretation } \\ \text { association }\end{array}$

Grounding-line fan Diamict: matrix-supported and massive. Isolated dropstones.

Diamict: matrix-supported and massive. Crude-bedding, erosional lower contacts and rip-up clasts.

Diamict: matrix-supported and stratified. Clast lags and sandy stringers.

Gravel: clast to matrix-supported, normal grading, channelized.

Gravel: clast to matrix-supported, inversely graded basal layer, channelized.

Sand: medium-fine, massive, channelized, erosional lower contacts, rip-up clasts, soft-sediment deformation structures.

Sand: medium-fine, variably graded, channelized, erosional lower contacts, rip-up clasts, soft-sediment deformation.

Sand: medium to fine, rippled, includes both types A- and B-climbing ripples. Typically associated with normally graded or massive sand, starved ripples and draped lamination.

Sand: fine to silt, draped lamination. Overlies rippled sands and occurs in close association with starved ripples and normally graded or massive sand.

Fines: horizontally laminated sand-silt couplets and silt-mud couplets. Contain occasional dropstones and drape underlying sediments.

Various: deformed. Thrust faults and contorted bedding.

\section{Morainal bank}

Diamict: matrix-supported and massive, with dispersed striated and facetted clasts, and rare paired bivalves. Concave-up clast lags and sandy stringers define individual beds of massive diamict. Contains occasional lenticular interbeds of poorly-sorted clast to matrix-supported, massive gravel (see below).

Diamict: matrix-supported, massive to weakly graded (variable coarse-tail). Stacked beds separated by sharp contacts or horizontally laminated sands. Large isolated clasts at bed tops.

Diamict: matrix-supported and massive with striated and facetted clasts. Directly overlies striated and ice-moulded bedrock and forms basal unit in morainal bank successions.

Gravel: poorly-sorted, clast to matrix-supported, massive. Occurs as lenticular interbeds with crudely erosional to deformed contacts within massive diamict.

Fines: horizontally laminated sand-silt couplets, occasional dropstones and paired bivalves. Normally graded sand laminae with sharp bases fining upwards into massive silt. Channelized.

Various: deformed. Contorted bedding, shear planes, penetrative deformation at base.
Rain-out of iceberg-rafted debris and suspended fines. Subaqueous cohesive debris flow.

Rain-out of iceberg-rafted debris and suspended fines, traction current reworking.

High-density turbidity currents in subaqueous outwash fan channels.

Cohesionless debris flow in subaqueous outwash fan channels.

High-density turbidity currents within subaqueous outwash fan channels.

High-density turbidity currents within subaqueous outwash fan channels.

Turbidity currents in interchannel or overbank areas of subaqueous outwash fan.

Suspension sedimentation from low-density turbidity currents in overbank and interchannel areas of subaqueous outwash fan.

Suspension sedimentation from turbid plume $<1 \mathrm{~km}$ (sand-silt couplets) and $>1 \mathrm{~km}$ (silt-mud) from the ice margin.

Glaciotectonic deformation.

Rain-out of coarse iceberg-rafted debris and suspended sediment. Lags and gravel interbeds record scour/scour and fill by subglacial meltwater jet in the zone of flow establishment.

Subaqueous mass flow.

Basal till.

Cut and fill by meltwater jet emanating from subglacial conduit. Gravels record rapid infilling of scours by hyperconcentrated flows.

Ice-proximal suspension deposition from turbid plume with minor ice rafting. Channels record initial erosion by meltwater jet emanating from subglacial conduit with subsequent passive infilling by fine-grained sediments.

Glaciotectonic deformation.
Prince of Wales Icefield on central Ellesmere Island: (1) through Bay Fiord (site 9, Fig. 1) extending northwards along the axis of Eureka Sound (site 8, Fig. 1) for 200 km; and (2) across northern Svendsen Peninsula (site 13, Fig. 1) and outer Baumann Fiord (site 14, Fig. 1). These dispersal trains directly overly striated and ice-moulded bedrock recording westerly ice flow, and are dominated by striated granite erratics. The principal source of these granite erratics is the Canadian Shield of southeastern Ellesmere Island which underlies the Prince of Wales Icefield (Fig. 1).

Dispersal trains and striated bedrock record the flow of warm-based ice into Eureka Sound from a former ice divide on central Ellesmere Island. Radiocarbon dates on glacially transported shell fragments from the granitic till and ${ }^{36} \mathrm{Cl}$ surface-exposure dates on granite erratics and adjacent bedrock indicate that the dispersal trains are late Wisconsinan
(Ó Cofaigh and others, 1998). Non-granitic till and deglacial landforms north and south of the dispersal trains indicate that these areas also supported extensive ice cover during the late Wisconsinan which was coalescent with the granitecarrying ice. The dispersal trains therefore record areas of preferential (warm-based) flow within a regional ice cover.

\section{Evidence of warm-based or polythermal ice during deglaciation}

Deglaciation of Ellesmere and Axel Heiberg Islands commenced prior to $10 \mathrm{kyr} \mathrm{BP}$, and resulted in glacioisostatic rebound of up to $150 \mathrm{~m}$. Consequently, large areas of the former sea floor are now exposed, allowing detailed investigations of early Holocene emergent glaciomarine deposits. These sediments form the building blocks of grounding-line 
fans, morainal banks and ice-contact deltas and record changes in both proximity of the ice margin to the depositional site and relative sea level (Fig. $3 \mathrm{a}$ and b; Bednarski, 1988; Evans, 1990; Stewart, 1991; Ó Cofaigh, 1998). The distribution of these deglacial landform-sediment assemblages exhibits a close relationship to fiord bathymetry, being most abundant where fiords are locally narrow and shallow, such as at fiord heads. These localities served as pinning points during deglaciation and hence as local glaciomarine depocentres. Between pinning points, deglacial landforms and sediments are commonly sparse or absent. This indicates that the retreat of fiord glaciers was controlled by bathymetry, with intervals of rapid ice recession between pinning points, punctuated by stabilization and deposition.

The following two sections describe landform-sediment assemblages deposited by late Quaternary fiord glaciers during deglaciation (Fig. 4 and Table 1). The data are based on observations of grounding-line fan and morainal-bank sequences on northern and western Ellesmere Island (Phillips Inlet, site 4, Fig. 1; Clements Markham Inlet, site 6, Fig. 1; Stewart, 1991; Trold Fiord, site 10, Fig. 1; Starfish Bay, site 12, Fig. 1). Many of these lithofacies document the importance of subglacial meltwater and are similar to those described from modern sub-polar and temperate glaciomarine settings (cf. Elverhøi and others, 1980; Powell and Molnia, 1989).

\section{Grounding-line fans}

Grounding-line fans form where sediment-laden meltwater debouches from a subglacial conduit into deep water (Powell and Molnia, 1989). Deposits typically consist of rapidly alternating gravel, sand, mud and diamict which record a wide variety of ice-proximal glaciomarine sedimentary processes (Table 1).

Sediment gravity-flow deposits are particularly common within grounding-line fans. These reflect the ice-proximal depositional setting, where high sedimentation rates coupled with minor ice-marginal fluctuations make deposits highly susceptible to failure and downslope transport. Channelized units of variably graded (normal or inverse to normal) cobble and pebble gravel, as well as amalgamated beds of massive or graded sand with erosional lower contacts, rip-up clasts and soft-sediment deformation structures are the product of high-density turbidity currents (cf. Postma, 1986; Fig. 4a). Thinly bedded partial Bouma sequences (Tac or Tace), rippled sands and draped lamination occur adjacent to channelized sands and likely record turbidity current deposition in interchannel areas. Massive and crudely bedded diamicts characterized by stacked beds, rip-up clasts of underlying sediment and erosional lower contacts, record subaqueous cohesive debris-flows.

Suspension and rain-out deposits also account for a large proportion of grounding-line fan sediments in the region. These comprise various diamict and interlaminated sandmud lithofacies (Table 1). Massive, matrix-supported diamicts are common and locally contain large isolated clasts and thin beds of horizontally laminated sand-silt couplets. Large clasts frequently deform, or are draped by, the finergrained interbeds. These lithofacies are interpreted to record rain-out of iceberg-rafted debris and suspension settling of fines (cf. Dowdeswell and others, 1994). Stratified, matrix-supported diamicts with sandy stringers and gravelly lags are inferred to record rain-out of coarse debris with intermittent traction-current activity. Thick sequences of interlaminated sand and silt, varying from graded couplets of very fine sand and sandy silt to silty clay with sand, are also common (Stewart, 1991). These lithofacies represent suspension deposits from turbid plumes emanating from subglacial conduits at the ice margin (cf. Mackiewicz and others, 1984).

\section{Morainal banks}

Morainal banks are subaqueous moraines formed along grounding lines during an interval of ice-margin stability. A significant part of their internal structure may be composed of overlapping grounding-line fans. Their elongate morphology reflects deposition from several point sources along the ice front and ice-marginal oscillations that bulldoze and squeeze sediment at the grounding line. Morainal bank size is controlled by the duration of grounding-line stability, availability of debris for entrainment and the rate of sediment flux to the ice margin (cf. Powell and Molnia, 1989). In Trold Fiord, southwestern Ellesmere Island (site 10, Fig. 1), an abundant basal debris supply and high sedimentation rates $\left(\sim 80 \mathrm{~mm} \mathrm{a}^{-1}\right)$, coupled with grounding-line stability of $\sim 400$ years, resulted in construction of an early Holocene morainal bank > $30 \mathrm{~m}$ high. In Phillips Inlet, northwestern Ellesmere Island (site 4, Fig. 1), morainal banks are commonly $<5 \mathrm{~m}$ high, reflecting a lack of available debris for entrainment by plateau glaciers that advanced across terrain with patchy or no sediment cover (thin residuum and bedrock) prior to reaching the sea (Evans, 1990).

Sedimentologically, morainal-bank deposits on Ellesmere and Axel Heiberg Islands range from simple diamict veneers over ice-moulded bedrock to a variety of glaciomarine lithofacies (Table 1). The latter include horizontally laminated fines consisting of sand-silt couplets with sparse dropstones and in-situ marine macrofauna (Fig. 4b and Table 1). Sand laminae grade normally from sharp bases upwards into massive silt. Laminated fines are interpreted to have been deposited by variable sediment fluxes from turbid plumes with limited rain-out of coarse iceberg-rafted debris (cf. Mackiewicz and others, 1984).

A range of diamict facies is observed. Massive, matrixsupported diamict with striated and facetted clasts directly overlying ice-moulded bedrock is interpreted as basal till. This contrasts with massive or weakly graded, matrix-supported diamict which occurs in stacked beds separated by sharp contacts or laterally continuous, thin 10-20 mm units of horizontally laminated sand. Individual beds exhibit weakly developed, normal or inverse coarse-tail grading, or are massive with larger clasts at bed tops (Fig. 4d), reflecting deposition from subaqueous mass flows with freighting of larger clasts (cf. Postma, 1986). Finally, massive, matrixsupported diamicts containing dispersed facetted clasts and rare paired bivalves, interbedded with horizontally laminated facies (Fig. 4c), are inferred to have originated by rain-out of coarse iceberg-rafted debris coupled with suspension settling of fines (cf. Dowdeswell and others, 1994). Concave-up clast lags within these diamicts record localized scour by subglacial meltwater.

\section{Evidence of cold-based ice during deglaciation}

Certain fiords exhibit early Holocene deglacial landformsediment assemblages markedly different to those described above. In Blind Fiord, southwestern Ellesmere Island (site 11, Fig. 1), fine-grained glaciomarine deposits and subaqueous outwash are absent above sea level. Rather, the deglacial geomorphic and sedimentary record is restricted to 
lateral meltwater channels and raised, coarse-grained glaciomarine deltas up to $130 \mathrm{~m}$ a.s.l.

The location and abundance of these deposits is closely related to fiord bathymetry. Pinning points are rare in the wide and deep central fiord, and raised glaciomarine deltas, where present, are poorly developed. These sediments connect upslope to nested, low-gradient, shallow lateral meltwater channels. This contrasts with the narrow and shallow inner fiord, where steep, well-developed, nested lateral meltwater channels grade to extensive accumulations of subaerial glaciofluvial outwash and raised glaciomarine deltas. Throughout the fiord, there is an absence of subaqueous outwash or fine-grained glaciomarine deposits, even at favorable pinning points (e.g. the fiord head). This absence of subaqueous outwash, coupled to the geomorphic dominance of lateral meltwater channels, suggests that the retreating trunk glacier was predominantly cold-based (cf. Dyke, 1993).

\section{DISGUSSION AND CONCLUSIONS}

\section{Implications for late Quaternary glaciation}

The above observations indicate that late Quaternary fiord glaciers in the Canadian High Arctic were characterized by variations in basal thermal regime. Some fiord glaciers were warm-based throughout much of their length during the LGM, moulding and striating underlying bedrock and depositing dispersal trains. During deglaciation, well-developed subglacial drainage systems delivered large volumes of sediment and meltwater to the ice margin, forming heterogeneous glaciomarine deposits. By contrast, other trunk glaciers appear to have lacked subglacial drainage systems during early Holocene retreat and meltwater evacuation occurred dominantly along their lateral margins, implying they were cold-based. Modern terrestrial glaciers on Ellesmere and Axel Heiberg Islands range from cold-based to polythermal and limited observations suggest that similar variability exists among modern marine-terminating glaciers.

The specific basal thermal regime of an individual fiord glacier was strongly influenced by the thickness and spatial extent of its accumulation area. Convergent flow from extensive upland icefields would have resulted in increased internal deformation and strain heating, particularly where fiords were narrow. This would have promoted frictional heating and sliding, facilitating development of warm-based or polythermal basal conditions. For example, Bay Fiord (site 9, Fig. 1) was a major conduit for convergent warmbased ice flow draining an expanded Prince of Wales Icefield (the primary regional ice divide during the LGM) and local ice caps bordering the fiord during the LGM. In contrast, fiords fed by thinner icefields with restricted accumulation areas were more likely to support cold-based outlet glaciers, e.g. Blind Fiord (site 11, Fig. 1).

Late Quaternary deglacial landform-sediment assemblages described above have been mapped by various workers as forming a regional "drift belt" (Hodgson, 1985) at the heads of many fiords on Ellesmere and Axel Heiberg islands (e.g. Bednarski, 1988; Lemmen and others, 1994). Terrain beyond this "drift belt" in many fiords is characterized by a sparsity of glaciogenic landforms and sediments (e.g. England, 1987; Ó Cofaigh, 1998). The strong spatial relationship between deglacial landform-sediment assemblages and pinning points within fiords, indicates that the location of early Holocene glaciomarine depocenters was predomin- antly controlled by fiord bathymetry. Pinning points facilitated glacier stabilization and sedimentation; thus fiord heads were especially favorable locations for ice-marginal stabilization and deposition, given their typically narrow widths and shallow water. Topographically controlled stabilization in the inner part of many fiords with subsequent extensive glaciogenic sedimentation, resulted in the development of a regional belt of fiord-head landforms that contrasts with a sparsity in many outer fiord areas, where deep water and wide fiords facilitated more rapid, continuous retreat.

The presence of this well-developed belt of deglacial landforms in the inner parts of many fiords which exhibit sedimentological evidence of subglacial meltwater deposition, combined with a sparsity of such features in the outer fiords, has previously been interpreted to mark a climatically driven change in the style of deglacial sedimentation (e.g. Evans, 1990; Lemmen, 1990; Stewart, 1991; Evans and England, 1992). This was based upon the interpretation that only minor advances of cold-based glaciers occurred during the LGM and was inferred to involve a transitory switch from cold- to warm-based thermal conditions during the early Holocene. However, recent glacial geological studies demonstrate extensive late Quaternary ice cover in this region (e.g. Blake, 1992; Bednarski, 1998; England, 1998; Ó Cofaigh and others, 1998). The fact that some constituent fiord glaciers appear to have been warm-based during the LGM and supported well-developed subglacial meltwater systems during deglaciation, combined with the spatial variation in basal thermal regime between retreating early Holocene fiord glaciers documented above, indicates that the predominant controls on basal thermal regime were related to more local glaciological variables and not climate. The most significant regional effect of warmer early Holocene climate (Bradley, 1990) was likely to facilitate increased ablation and associated glaciomarine sedimentation.

\section{AGKNOWLEDGEMENTS}

Much of this research was originally conducted by the authors as part of the Palaeoenvironmental Change in the Canadian High Arctic program, headed byJ. England, University of Alberta (Natural Sciences and Engineering Research Council of Canada grant A6680; logistical support provided by Polar Continental Shelf Project, Natural Resources Canada). We thank him for the opportunity to undertake this work and for all the discussion over the years. Additional financial support for this research was provided by the Canadian Circumpolar Institute, University of Alberta, and the Young ResearchWorkers Awards, Quaternary Research Association. D. J. A. Evans gratefully acknowledges financial support from the Royal Society for recent work in the Canadian High Arctic. We thank M.J. Sharp, University of Alberta, and A.S. Dyke for their comments on the manuscript. D. M. Mickelson and S. J. Fitzsimons provided thorough formal reviews which significantly clarified many aspects of the paper. This paper is Geological Survey of Canada contribution no. 1998168 and Polar Continental Shelf Project contribution no. 004098.

\section{REFERENCES}

Bednarski, J. 1988. The geomorphology of glaciomarine sediments in a High Arctic fiord. Géogr. Phys. Quat., 42(1), 65-74.

Bednarski, J. 1998. Quaternary history of Axel Heiberg Island bordering 
Nansen Sound, Northwest Territories, emphasizing the last glacial maximum. Can. 7. Earth Sci., 35(5), 520-533.

Bergsma, B. M., J. Svoboda and B. Freedman. 1984. Entombed plant communities released by a retreating glacier at central Ellesmere Island, Canada. Arctic, 37(1), 49-52.

Blake, W., Jr. 1992. Holocene emergence at Cape Herschel, east-central Ellesmere Island, Arctic Canada: implications for ice sheet configuration. Can. F. Earth Sci., 29(9), 1958-1980.

Blatter, H. 1987. On the thermal regime of an Arctic valley glacier: a study of White Glacier, Axel Heiberg Island, N.W.T., Canada. 7. Glaciol., 33(114), 200-211.

Boulton, G. S. 1972. The role of thermal régime in glacial sedimentation. In Price, R.J. and D.E. Sugden, comps. Polar geomorphology. London, Institute of British Geographers, 1-19.

Bradley, R. S. 1990. Holocene paleoclimatology of the Queen Elizabeth Islands, Canadian High Arctic. Ouat. Sci. Rev., 9(4), 365-384.

Clayton, L. and S. R. Moran. 1974. A glacial process-form model. In Coates, D. R., ed. Glacial geomorphology. Binghamton, NY, State University of New York, 89-119.

Dowdeswell, J. A., R. J. Whittington and P. Marienfeld. 1994. The origin of massive diamicton facies by iceberg rafting and scouring, Scoresby Sund, East Greenland. Sedimentology, 41 (1), 21-35.

Dyke, A. S. 1993. Landscapes of cold-centred Late Wisconsinan ice caps, Arctic Canada. Prog. Phys. Geogr., 17(2), 223-247.

Echelmeyer, K. and Wang Zhongxiang. 1987. Direct observation of basal sliding and deformation of basal drift at sub-freezing temperatures. $\mathcal{F}$. Glaciol., 33(113), 83-98.

Elverhøi, A., O. Liestøl and J. Nagy. 1980. Glacial erosion, sedimentation and microfauna in the inner part of Kongsfjorden, Spitsbergen. Nor Polarinst. Skr. 172, 33-61.

England, J. 1987. Glaciation and the evolution of the Canadian High Arctic landscape. Geology, 15(5), 419-424.

England, J. 1998. Support for the Innuitian Ice Sheet in the Canadian High Arctic during the Last Glacial Maximum. 7. Quat. Sci., 13(3), 275-280.

Evans, D. J. A. 1989a. Apron entrainment at the margins of sub-polar glaciers, north-west Ellesmere Island, Canadian High Arctic. 7. Glaciol. 35(121), 317-324.

Evans, D. J. A. 1989b. The nature of glacitectonic structures and sediment at sub-polar glacier margins, northwest Ellesmere Island, Canada. Geogr. Ann., 71A (3-4), 113-123.

Evans, D. J. A. 1990. The effect of glacier morphology on surficial geology and glacial stratigraphy in a high Arctic mountainous terrain. Z. Geomorphol., 34(4), 481-503.

Evans, D. J. A. and J. England. 1992. Geomorphological evidence of Holocene climatic change from northwest Ellesmere Island, Canadian High Arctic. Holocene, 2(2), 148-158.

Gilbert, R. and A. E. Aitken. In press. Preliminary results on the Quaternary sedimentary environment and benthos of part of Cañon Fiord, Fosheim Peninsula, Ellesmere Island. In Garneau, M., ed. Environmental response to climate change in the Canadian High Arctic. Ottawa, Ont., Geological Survey of Canada.

Gilbert, R., A. E. Aitken and D. S. Lemmen. 1993. The glacimarine sedimentary environment of Expedition Fiord, Canadian High Arctic. Mar. Geol., $110(3 / 4), 257-273$.
Hattersley-Smith, G. 1969. Recent observations on the surging Otto Glacier, Ellesmere Island. Can. 7. Earth Sci., 6(4, Part 2), 883-889.

Hodgson, D. A. 1985. The last glaciation of west-central Ellesmere Island, Arctic Archipelago, Canada. Can. 7. Earth Sci., 22(3), 347-368.

Iken, A. 1972. Measurements of water pressure in moulins as part of a movement study of the White Glacier, Axel Heiberg Island, Northwest Territories, Canada. 7. Glaciol., 11 (61), 53-58.

Kälin, M. 1971. The active push moraine of the Thompson Glacier, Axel Heiberg Island, Canadian Arctic Archipelago, Canada. Montréal, Que., McGill University. (Axel Heiberg Island Research Reports. Glaciology 4.)

Koerner, R.M. 1989. Queen Elizabeth Islands glaciers. In Fulton, R.J., ed. Quaternary geology of Canada and Greenland. Geology of Canada 1. Chapter 6: Quaternary geology of the Queen Elizabeth Islands. Ottawa, Ont., Geological Survey of Canada; Boulder, CO, Geological Society of America, 464478. (The Geology of North America K-1.)

Lemmen, D. S. 1990. Glaciomarine sedimentation in Disraeli Fiord, High Arctic, Canada. Mar. Geol., 94(1/2), 9-22.

Lemmen, D. S., A. E. Aitken and R. Gilbert. 1994. Early Holocene deglaciation of Expedition and Strand Fiords, Canadian High Arctic. Can. 7 . Earth Sci., 31(6), 943-958.

Mackiewicz, N. E., R. D. Powell, P. R. Carlson and B. F. Molnia. 1984. Interlaminated ice-proximal glacimarine sediments in Muir Inlet, Alaska. Mar. Geol., 57(1/4), 113-147.

Müller, F. 1976. On the thermal regime of a high-Arctic valley glacier. $\mathcal{F}$. Glaciol., 16(74), 119-133.

Ó Cofaigh, C. 1998. Geomorphic and sedimentary signatures of early Holocene deglaciation in High Arctic fiords, Ellesmere Island, Canada: implications for deglacial ice dynamics and thermal regime. Can. 7 . Earth Sci., 35(4), 437-452.

Ó Cofaigh, C., J. England and M. Zreda. 1998. Configuration and dynamics of Late Wisconsinan glaciation, southern Eureka Sound, High Arctic Canada. Geol. Soc. Am. Abstr. Programs, 30, Al12.

Ommanney, C. S. L. 1969. A study in glacier inventory: the ice masses of Axel Heiberg Island, Canadian Arctic Archipelago. Montréal, Que., McGill University. (Axel Heiberg Island Research Reports. Glaciology 3.)

Postma, G. 1986. Classification for sediment gravity flow deposits based on flow conditions during sedimentation. Geology, 14(4), 291-294.

Powell, R. D. 1984. Glacimarine processes and inductive lithofacies modelling of ice shelf and tidewater glacier sediments based on Quaternary examples. Mar. Geol., 57(1/4), 1-54.

Powell, R. D. and B. F. Molnia. 1989. Glacimarine sedimentary processes, facies and morphology of the south-southeast Alaska Shelf and fjords. Mar. Geol., 85(2/4), 359-390.

Powell, R. D., M. Dawber, J. N. McInnes and A. R. Pyne. 1996. Observations of the grounding-line area at a floating glacier terminus. Ann. Glaciol., 22, 217-223.

Rains, R. B. and J. Shaw. 1981. Some mechanisms of controlled moraine development, Antarctica. f. Glaciol., 27(95), 113-128.

Skidmore, M. and M. Sharp. In press. Drainage system behaviour of a High Arctic polythermal glacier. Ann. Glaciol., 28 (see paper in this volume).

Stewart, T. G. 1991. Glacial marine sedimentation from tidewater glaciers in the Canadian High Arctic. In Anderson, J. B. and G. M. Ashley, eds. Glacial marine sedimentation; paleoclimatic significance. Boulder, CO, Geological Society of America, 95-105. (GSA Special Paper 261.) 